\title{
Respon Kecepatan Angin Terhadap Variabilitas Klorofil-a di Laut Filipina Dan Maluku Bagian Utara
}

\author{
Bayu Munandar ${ }^{*}$, Anindya Wirasatriya ${ }^{2}$, Denny Nugroho Sugianto², Ambariyanto1, \\ Sunaryo ${ }^{1}$
}

\author{
${ }^{1}$ Departemen Ilmu Kelautan, Fakultas Perikanan dan Ilmu Kelautan, Universitas Diponegoro \\ ${ }^{2}$ Departemen Oseanografi, Fakultas Perikanan dan Ilmu Kelautan, Universitas Diponegoro \\ J1. Prof. H. Soedarto S.H, Tembalang, Semarang, Jawa Tengah 50275 Indonesia \\ Email: bymunandar@gmail.com
}

\begin{abstract}
Abstrak
Suplay massa air di Laut Filipina dan Maluku bagian utara berasal dari Samudera Pasifik. Variabilitas klorofil-a (chl-a) dapat dipengaruhi oleh suplay massa air dari suatu wilayah atau pengaruh interaksi atmosfer dan laut. Penelitian bertujuan untuk menjelaskan pengaruh interaksi atmosfer-laut terhadap variabilitas chl-a secara spasial dan temporal. Data yang digunakan yaitu data citra satelit dengan periode 2003-2019 dan argo float. Hasil menunjukkan chl-a di Laut Filipina selalu berada dibawah $0,1 \mathrm{mg} / \mathrm{m}^{3}$ di sepanjang tahun dan Laut Maluku bagian utara mengalami peningkatan saat musim timur $\left(0,27 \mathrm{mg} / \mathrm{m}^{3}\right)$. Kenaikan chl-a di Laut Maluku bagian utara diikuti dengan kenaikan kecepatan angin (musim timur) yang menyebabkan Ekman Mass Transport (EMT). EMT bergerak kearah timur laut yang membawa massa air menjauhi pantai dan terjadi proses coastal upwelling. Coastal upwelling inilah menjadi faktor utama peningkatan chl-a di Laut Maluku bagian utara. Sebaliknya, kenaikan kecepatan angin di Laut Filipina tidak membangkitkan EMT dan tidak meningkatkan chl-a. Chl-a yang stabil di sepanjang tahun di Laut Filipina membuktikan kecepatan angin kuat tidak terlalu dominan untuk mempengaruhi variabilitas chl-a. Rendahnya chl-a kemungkinan disebakan oleh massa air dari Samudera Pasifik yang dibawa oleh Arus Lintas Indonesia (ARLINDO).
\end{abstract}

Kata kunci: Klorofil-a, Coastal Upwelling, Laut Maluku, Laut Filipina

\section{Abstract \\ Response of Wind Speed on Chlorophyll-a Variability in the Philippine Sea and North Maluku Sea}

Water mass supply in the Philippine Sea and northern Maluku derived from the Pasific Ocean. The variability of chlorophyll-a (chl-a) was affected by the supply of water mass from the area or the impact of air and sea interactions. This study aimed to define the effect of air-sea interaction on the spatial and temporal variability of chl-a. The required data in this study was satellite image data with the period 20032019 and argo float. The results showed that chl-a in the Philippine Sea was always below $0.1 \mathrm{mg} / \mathrm{m} 3$ throughout the year and the northern Maluku Sea increased during the eastern monsoon $(0.27 \mathrm{mg} / \mathrm{m} 3)$. The increasing of chl-a in the northern Maluku Sea was followed by the increasing of wind speed (east monsoon) which impacted the Ekman Mass Transport (EMT). EMT moved to the northeast carrying the water mass away from the coast and turned up coastal upwelling process. Coastal upwelling was the main factor of chla increasing in the North Maluku Sea. In otherwise, wind speed increasing in the Philippine Sea caused vertical mixing (west monsoon) but did not increase chl-a. The stable value of chl-a throughout the years in the Philippine Sea verified that strong wind speeds are not too dominant to affect the variability of chl-a.. The low chl-a was probably caused by the water mass from the Pacific Ocean that carried by Indonesian Through Flow (ARLINDO).

Keywords: Chlorophyll-a, Coastal Upwelling, Maluku Sea, Philippine Sea 


\section{PENDAHULUAN}

Laut Filipina dan Maluku bagian utara terletak diantara perairan Indonesia dan Filipina (Gambar 1). Perairan ini merupakan pintu masuk ARLINDO yang menghubungkan Samudera Pasifik dan Samudera Hindia (Susanto et al., 2007). Laut Filipina memiliki kedalaman perairan lebih dari 3000 meter dan Laut Maluku bagian utara berkisar 1500 meter (Nugroho et al., 2018). Perairan ini memiliki sumber massa air yang sama yaitu north equatorial current, sehingga mempengaruhi distribusi klorofil-a, salinitas, suhu, dan lainnya (Gordon, 2005; Ando and McPhaden, 1997). Selain faktor ARLINDO, interaksi atmosfer-laut menjadi faktor penting dalam variasi fitoplankton secara spasial dan temporal. Tingginya konsentrasi fitoplankton dipengaruhi oleh suplay nutrien di permukaan perairan. Suplay nutrien bisa terjadi akibat fenomena fisika yang ada di perairan, dimana dapat mendistribusikan nutrien secara horizontal dan vertikal (Wang and Tang, 2014). Angin merupakan variabel penting dalam interaksi atmosfer-laut. Variasi angin monsoon sangat berpengaruh terhadap variabilitas SST dan klorofil-a di Laut Maluku dan Laut Filipina (Wirasatriya et al., 2019).
Sejauh ini, sedikit penelitian mengenai interaksi atmosfer-laut terhadap variabilitas klorofil-a secara temporal dan spasial di perairan ini. Laut Maluku bagian utara dan Laut Filipina dihubungkan oleh Mindanao Current (MC) (Susanto et al., 2007). MC yang mengalir dari Laut Filipina menuju Laut Sulawesi dan Laut Maluku memiliki kecepatan sebesar $1 \mathrm{~m} / \mathrm{s}$ di kedalaman sekitar 200 meter, sehingga mempengaruhi distribusi massa air di perairan ini (Schönau et al., 2015). Menurut Wirasatriya et al., (2019), coastal upwelling terjadi di Laut Maluku bagian utara pada musim timur diakibatkan oleh angin monsoon tenggara yang menyebabkan penurunan suhu. Penelitian diatas hanya fokus pada monsoon tenggara (Juli - September) sehingga tidak dapat menggambarkan pola distribusi seluruh musim. Variasi El Niño Southern Oscillation (ENSO) mempengaruhi variablitas klorofil-a dan SST di Laut Maluku (Wirasatriya et al., 2017). Penelitian (Wirasatriya et al., 2017; Wirasatriya et al., 2019) memfokuskan wilayah penelitian di Laut Maluku, dan tidak memperluas wilayah sampai ke Laut Filipina karena kedua perairan ini memiliki sumber massa air yang sama dan distribusi angin yang barkaitan.

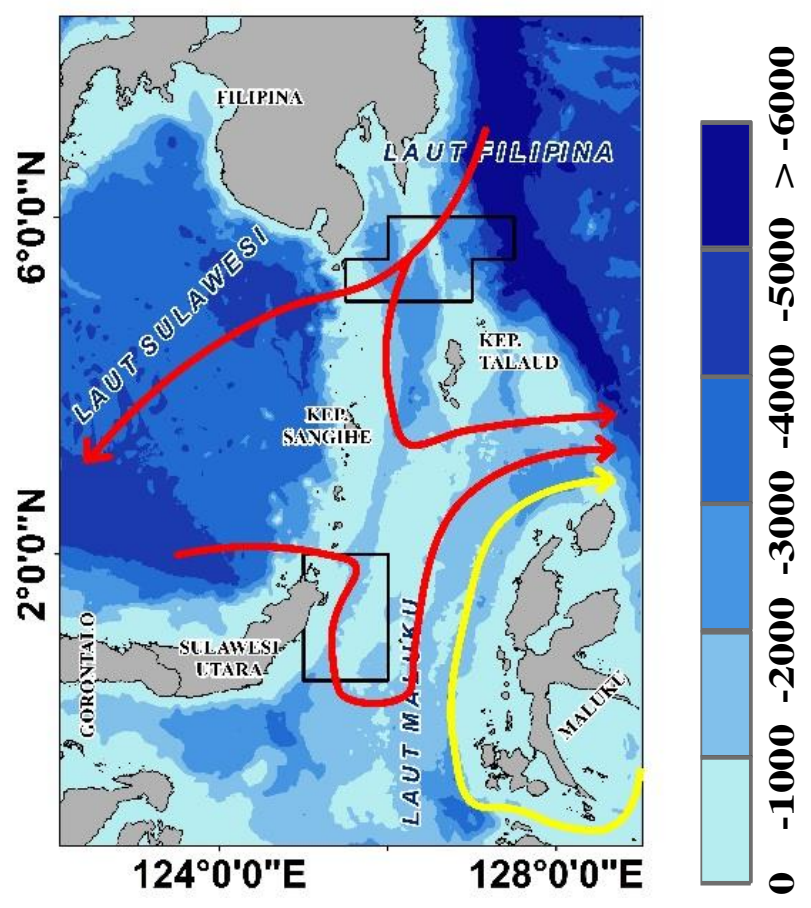

Gambar 1. Lokasi Penelitian. Panah merah menunjukkan ARLINDO yang berasal dari Mindanao Current dan panah kuning berasal dari Halmahera Eddy 
Penelitian mengenai pengaruh atmosfer-laut terhadap variasi spasial dan temporal klorofil-a di Laut Filipina dan Laut Maluku bagian utara sangatlah penting. Perairan Laut Maluku termasuk ke dalam WPP-716 dan 715 yang memiliki potensi perikanan yang besar. Variasi klorofil-a secara spasial dan temporal menjadi faktor migrasi dari ikan di suatu perairan, sehingga dapat memprediksi pola fishing ground. Oleh karena itu, penelitian ini menjelaskan pengaruh interaksi atmosfer-laut terhadap variabilitas klorofil-a secara spasial dan temporal.

\section{MATERI DAN METODE}

Penelitian ini menggunakan estimasi fitoplankton (chl-a) yang didapatkan dari Ocean Colour Climate Change Initiative (OC-CCI) sebagai data primer. Resolusi data yaitu $0,04^{0} \mathrm{x}$ $0,04^{0}$ dengan periode perekaman harian. Periode data yang digunakan yaitu 2003 - 2019. OC-CCI chl-a merupakan projek gabungan antara National Aeronautics and Space Administration (NASA) dan European Space Agency (ESA). OC-CCI berasal dari gabungan antara beberapa citra satelit (MODIS, MERIS, SeaWIFS, Sentinel-3A).

Data angin (komponen meridional dan zonal) didapatkan dari Cross-Calibrated MultiPlatform (CCMP). Resolusi data CCMP yaitu $0,25^{\circ} \times 0,25^{\circ}$ (longitude $\mathrm{x}$ latitude). CCMP merupakan data reanalisis yang berasal dari citra satelit, moored buoy dan model. Periode data yang digunakan yaitu $2003-2019$.

Distribusi vertikal Sea Surface Temperature (SST) dan salinitas menggunakan data argo float. Data SST dan salinitas digunakan untuk mengetahui distribusi vertikal densitas. Data argo float didapatkan dari www.oceanops.org/board?t=argo dengan kedalaman berkisar $0-2000$ meter. Topography menggunakan data Global 30 Arc-Second Elevation (GTOPO30) dan bathimetry menggunakan General Bathymetric Chart Of The Oceans (GEBCO).

Analisis data yang digunakan berdasarkan data klimatologi. Data klimatologi didapatkan dari data harian yang di rata-rata menjadi klimatologi bulanan menggunakan rumus berikut (Wirasatriya et al., 2017):

$$
\bar{T}=\frac{1}{n} \sum_{i=1}^{n} x_{i}
$$

Keterangan $: \bar{T}=$ Rata - rata; $n=$ Jumlah data; $x_{i}=$ Nilai data
Pengaruh kecepatan angin terhadap chl-a dapat diidentifikasi dengan menghitung nilai EMT menggunakan data CCMP. Sebagian wilayah penelitian berada di sekitar equator yang memungkinkan nilai coriolis sama dengan 0 . Lokasi penelitian yang berada di sekitar equator, sehingga perlu menggunakan rumus EMT untuk daerah dekat equator berikut (Hsieh \& Boer, 1992):

$$
\begin{aligned}
\tau & =\rho_{a} C_{d} U_{10}^{2} \\
E M T_{x} & =\frac{\left(\delta \tau_{x}+f \tau_{y}\right)}{\rho_{w}\left(f^{2}+\delta^{2}\right)} \\
E M T_{y} & =\frac{\left(\delta \tau_{y}-f \tau_{x}\right)}{\rho_{w}\left(f^{2}+\delta^{2}\right)}
\end{aligned}
$$

Keterangan : $\rho_{a}=$ Densitas udara $\left(1,25 \mathrm{~kg} \cdot \mathrm{m}^{-3}\right)$; $\rho_{w}=$ Densitas air $\left(1,025 \mathrm{~kg} \cdot \mathrm{m}^{-3}\right) ; U_{10}=$ Kecepatan angin $\left(\mathrm{m} / \mathrm{s}^{2}\right) ; C_{d}=$ Koefisien Gesek (WAMDI, 1988); $E M T_{x, y}=$ EMT komponen zonal dan meridional; $f=$ Parameter Coriolis $(2 \Omega \sin \varphi)$; $\delta=$ Frictional dumping parameter $\left(480^{-1}\right.$ days $)$

\section{HASIL DAN PEMBAHASAN}

Distibusi chl-a di Laut Maluku bagian utara dan Laut Filipina digambarkan sepanjang musim. Kedua perairan tersebut sangat berdekatan dan tidak ada pembatas antar laut tersebut dan dihubungkan oleh arus yang berasal dari Samudera Pasifik (Gambar 1). Lokasi perairan yang berdekatan tidak membuat variasi chl-a di perairan tersebut sama. Distribusi chl-a (Gambar 2) menunjukkan karakteristik yang berbeda di Laut Maluku bagian utara dan Laut Filipina. Distribusi spasial chl-a (Gambar 2) di Laut Filipina terlihat rendah sepanjang tahun dan Laut Maluku bagian utara lebih tinggi dan meningkat di musim timur.

Variasi temporal chl-a dan kecepatan angin di Laut Maluku bagian utara dan Laut Filipina terlihat pada Gambar 3. Konsentrasi chl-a di Laut Maluku bagian utara terendah saat musim peralihan 1 (April) sebesar $\pm 0,13 \mathrm{mg} / \mathrm{m}^{3}$, memasuki musim timur chl-a meningkat dua kali menjadi $0,27 \mathrm{mg} / \mathrm{m}^{3}$ (Gambar 3). Laut Filipina memiliki konsentrasi chl-a selalu kurang dari 0,07 $\mathrm{mg} / \mathrm{m}^{3}$ di sepanjang tahun. Konsentrasi chl-a di Laut Maluku bagian utara lebih besar 4 kali dibandingkan dengan Laut Filipina saat musim timur. 
Perbedaan chl-a di musim timur yang besar tidak sama dengan nilai kecepatan angin. Hal menarik terlihat di Laut Maluku bagian utara dan Laut Filipina yaitu kedua perairan memiliki kecepatan angin yang sama di musim timur (Gambar 3). Kecepatan angin musim timur tercatat sebesar $5,3 \mathrm{~m} / \mathrm{s}$ di kedua perairan. Jian et al., (2012) menjelaskan kecepatan angin dan chl-a memiliki korelasi positif, dimana semakin tinggi kecepatan angin membuat konsentrasi chl-a meningkat. Hal diatas tidak terjadi di Laut Filipina tetapi terbukti di Laut Maluku bagian utara.
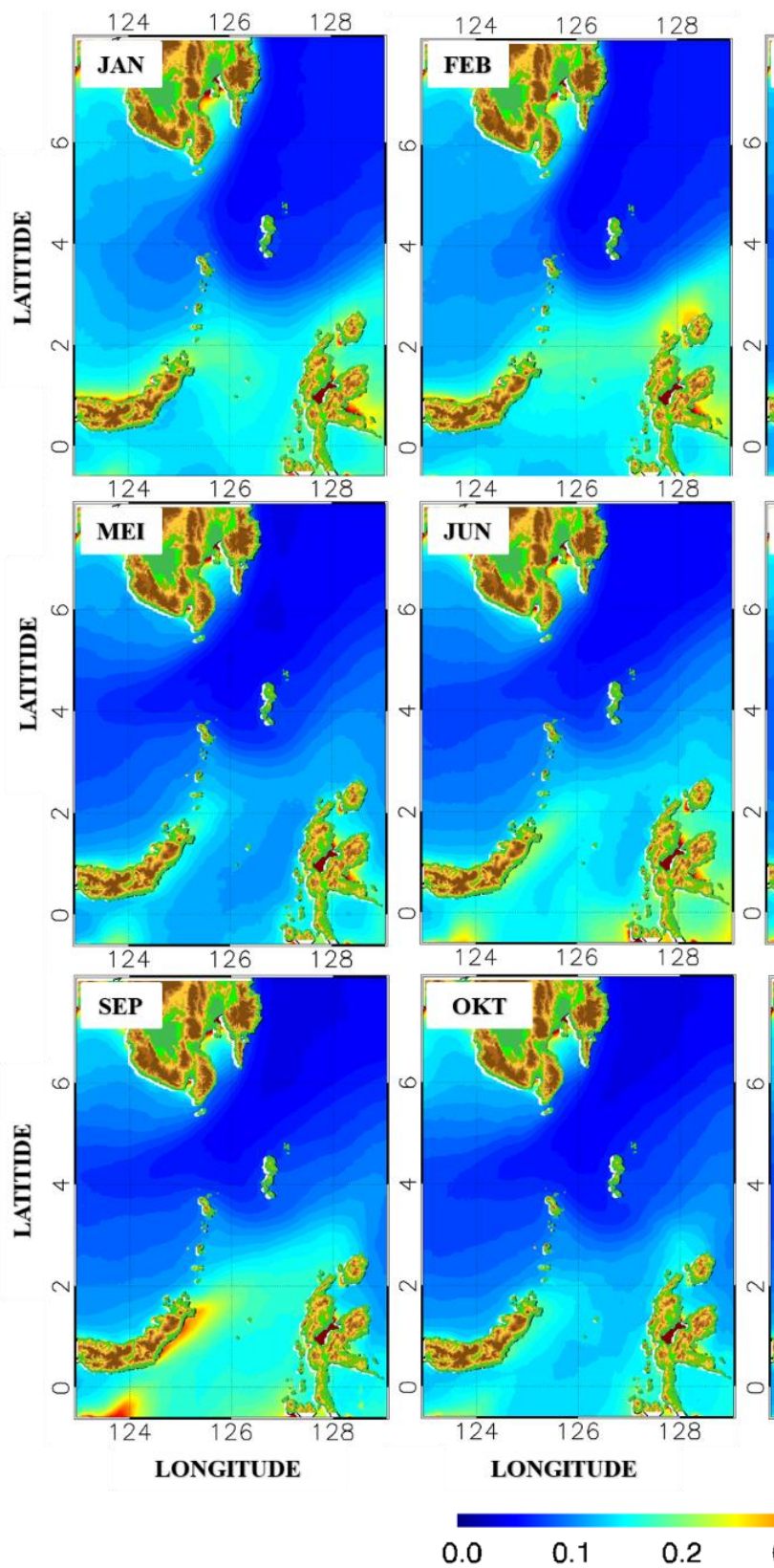

Lokasi penelitian berada di lepas pantai membuat pengaruh daratan terhadap nilai chl-a menjadi minimum. Minimum pengaruh run off daratan terlihat dari nilai normalized waterleaving radiance 555 (nLw 555). nLw 555 dapat menjadi indikator konsentrasi sedimen di perairan (Acker et al., 2004). Peningkatan chl-a di perairan dan disertai penurunan absorbansi fitoplankton (normalized water-leaving radiance 443 (nLw 443)) dapat menghasilkan data chl-a yang lebih akurat (Shi \& Wang, 2007). Laut Maluku bagian utara memiliki chl-a tertinggi (Agustus) (Gambar 3), nLw 443 terendah (Agustus) (Gambar 4) dan

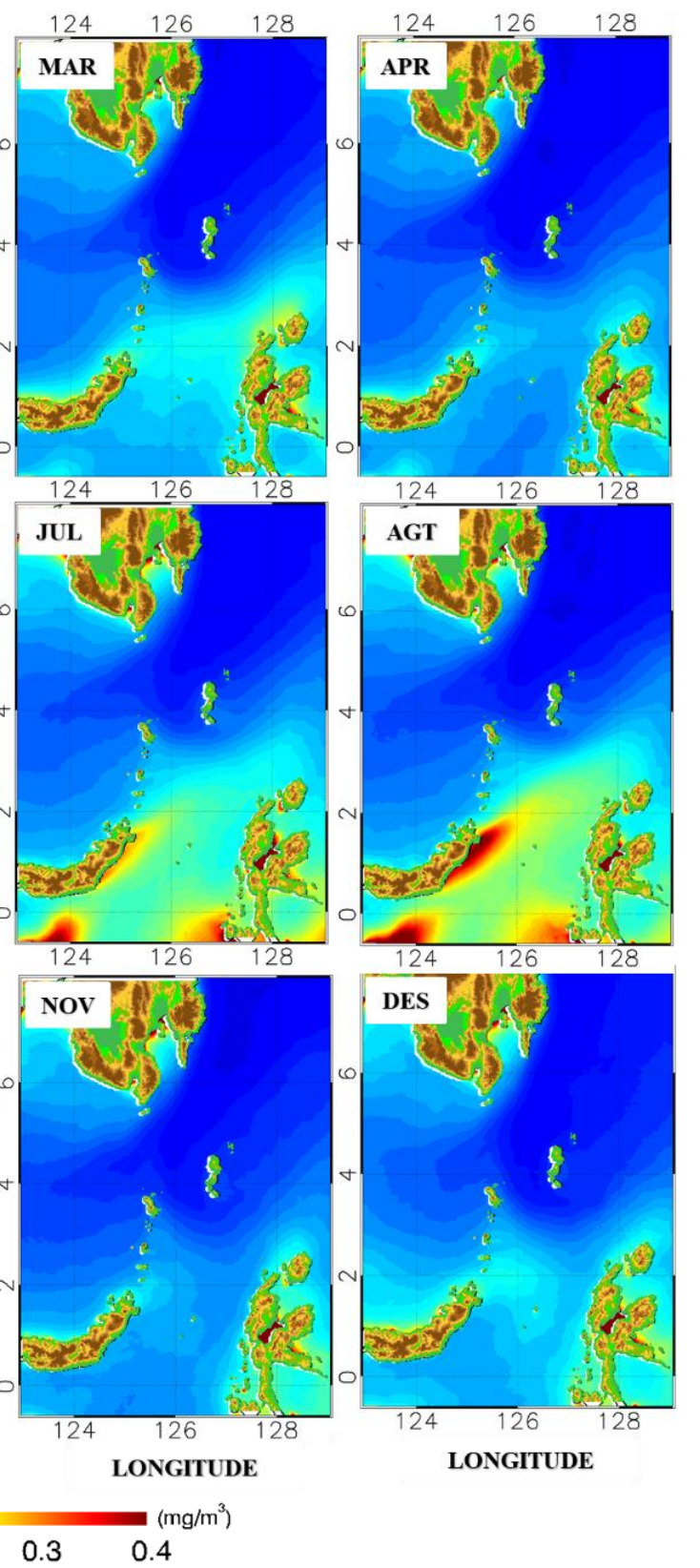

Gambar 2. Distribusi bulanan klorofil-a (2003 - 2019) 
nLw 555 stabil sepanjang tahun (Gambar 4) dan Laut Filipina memiliki pola yang sama (stabil sepanjang tahun) (Gambar 3 dan 4). Data tersebut menunjukkan variabilitas chl-a di kedua perairan tersebut tidak didominasi oleh pengaruh daratan. Proses utama yang mengatur variabilitas chl-a di permukaan laut yaitu kecepatan angin (Wang and Tang, 2014). Kedua perairan memiliki kecepatan angin yang tinggi saat musim timur dan lokasi geografis keduanya menjadi faktor pembeda yang sangat penting. Peningkatan kecepatan angin di Maluku bagian utara meningkatkan EMT yang menjauhi pantai, tetapi Laut Filipina tidak terjadi (Gambar 5). EMT di Laut Maluku bagian utara terjadi pada bulan Agustus $\left( \pm 20 \mathrm{~m}^{2} / \mathrm{s}\right)$ dan bergerak ke timur laut (Gambar 5b).

Perbedaan arah angin dan EMT disebabkan karena adanya gaya coriolis. Lokasi yang berada di belahan bumi utara membuat arah dibelokkan ke kanan sebesar $45^{\circ}$ (Trujillo and Thurman, 2011). EMT yang menjauhi pantai (Gambar 5b) dapat menimbulkan fenomena coastal upwelling (Wirasatriya et al., 2019). Fenomena coastal upwelling terbukti dengan adanya pergerakan nilai densitas secara konstan dari kedalaman 50 meter menuju permukaan saat musim timur(Gambar 6b). Densitas musim barat terlihat homogen dari kedalaman 0-40 meter (Gambar 6a).

Menurut Wang dan Tang (2014) coastal upwelling mengangkut nutrien yang berada di kolom perairan menuju permukaan dan dimanfaatkan fitoplankton untuk proses fotosintesis. Proses tersebut menyebabkan kenaikan chl-a dua kali lebih tinggi pada saat musim timur. Laut Maluku bagian utara dan Laut Filipina memiliki kesamaan yaitu kecepatan angin yang kuat (Gambar 3). Kuatnya kecepatan angin di Laut Filipina tidak menimbulkan ekman transport, sehingga tidak ada cosatal upwelling. Tidak adanya coastal upwelling terlihat dari data argo float musim barat dan musim timur yang memiliki densitas yang homogen. Kenaikan kecepatan angin (Gambar 3) tidak mempengaruhi dinamika massa air di kolom perairan (Gambar 6b). Densitas yang homogen di kedalaman 0-50 membuktikan interaksi atmosfer dan laut di Laut

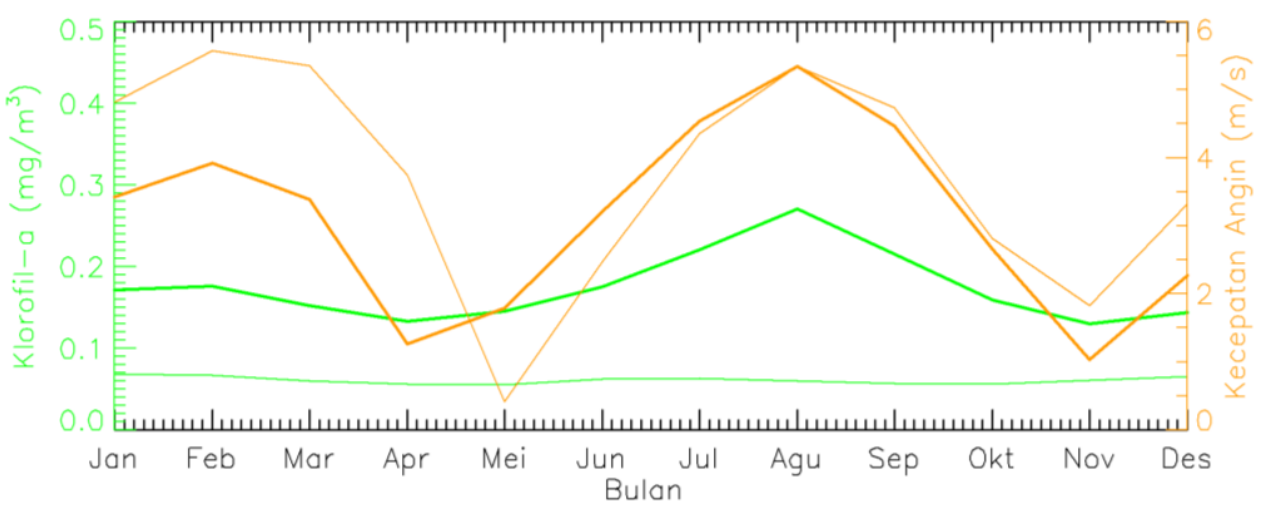

Gambar 3. Rata - rata bulanan kecepatan angin dan klorofil-a 2003 - 2019 di Laut Maluku bagian utara (garis tebal) dan Laut Filipina ( garis tipis).

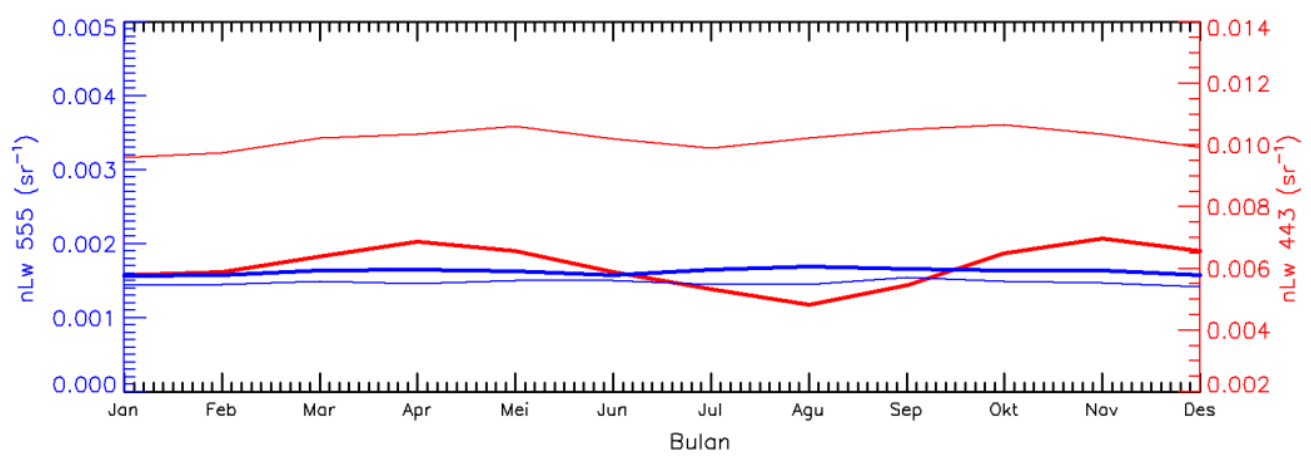

Gambar 4. Rata - rata bulanan nLw 443 dan 555 (MODIS) 2003 - 2019 di Laut Maluku bagian utara (0,5 2 LU, 125 - 127 BT; garis tebal) dan Laut Filipina (5 - 6 LU, 125,5 - 127,5 BT; garis tipis) 


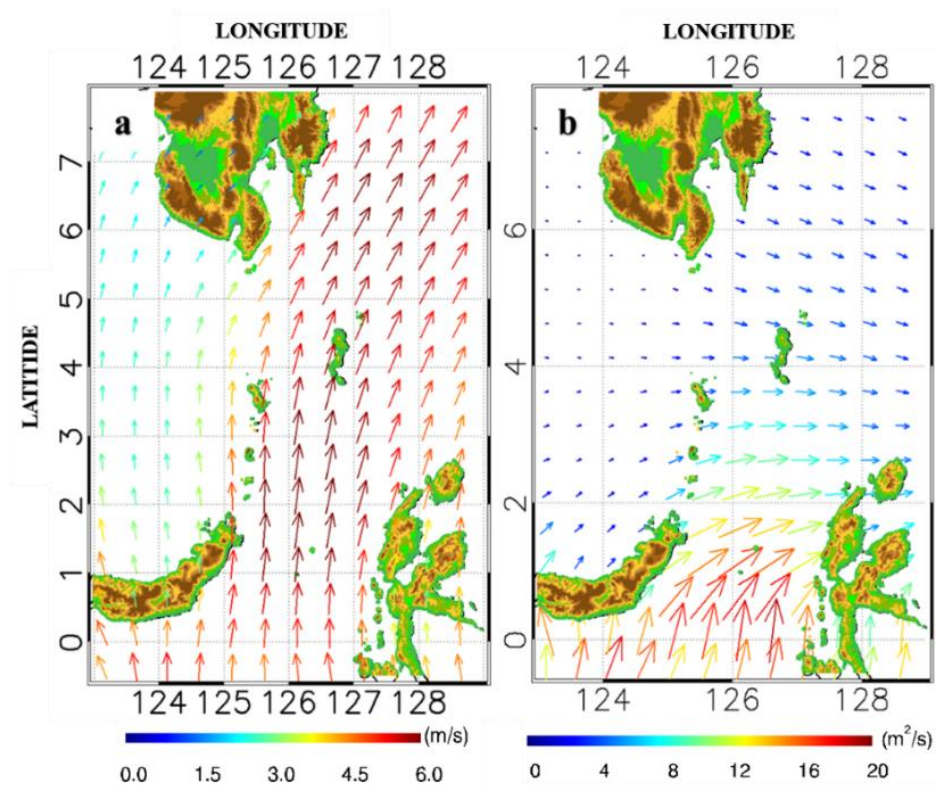

Gambar 5. Distribusi bulanan a) kecepatan angin dan b) EMT

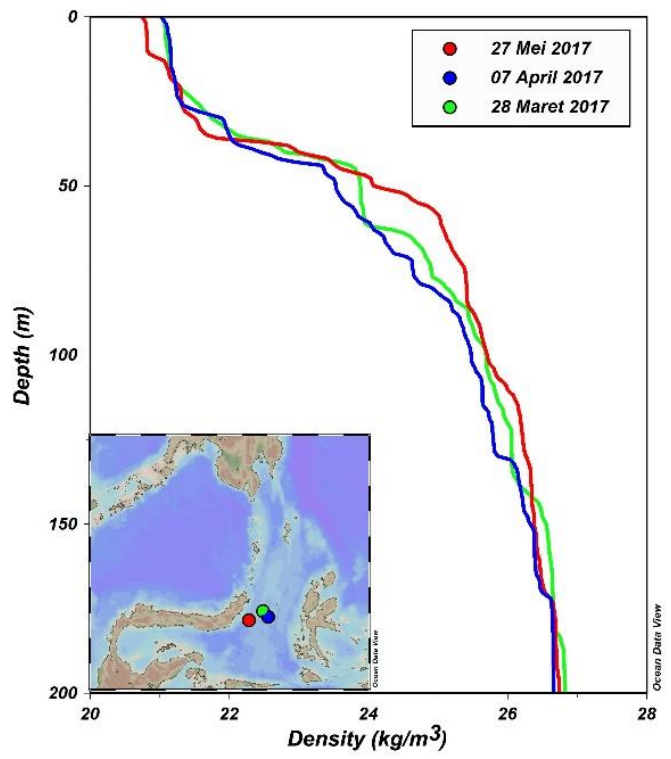

a

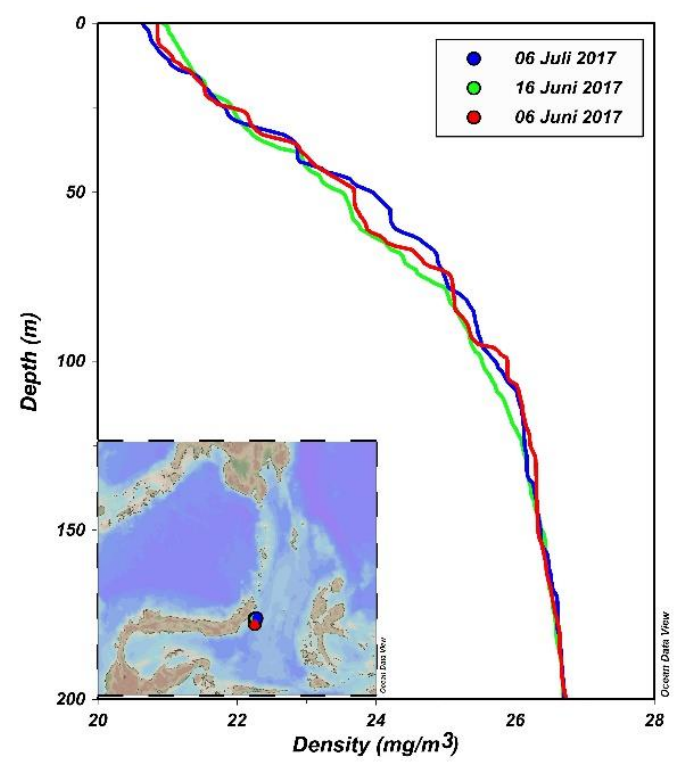

b

Gambar 6. Profil vertikal densitas bulanan di Laut Maluku bagian utara a). argo float musim barat b). argo float musim timur.

Filipina tidak dominan untuk meningkatkan chl-a. Laut Filipina merupakan pintu utama masuknya massa air dari Samudera Pasifik (Susanto and Song, 2014) membuat massa air di peraian tersebut sangat dipengaruhi oleh massa air Samudera Pasifik. MC yang membawa massa air samudera pasifik terjadi sepanjang tahun dan bulan Januari - Maret memiliki arus yang lebih kuat dibandingkan dengan bulan yang lain (Ren $e t$ al., 2018).
Perbedaan chl-a di Laut Maluku bagian utara dan Laut Filipina dikarenakan adanya proses coastal upwelling. Chl-a merupakan parameter biologi di lingkungan perairan dan berhubungan dengan produktivitas perikanan (Sachoemar et al., 2012). Nurdin et al., (2017) menyatakan chl-a dapat mempengaruhi distribusi ikan pelagis, dimana nilai chl-a berkisar antara $\pm 0,5 \mathrm{mg} / \mathrm{l}$ (Zainuddin et al., 2017). FAO (2000) menyatakan Laut Filipina pada tahun 1992 -1995 memiliki 


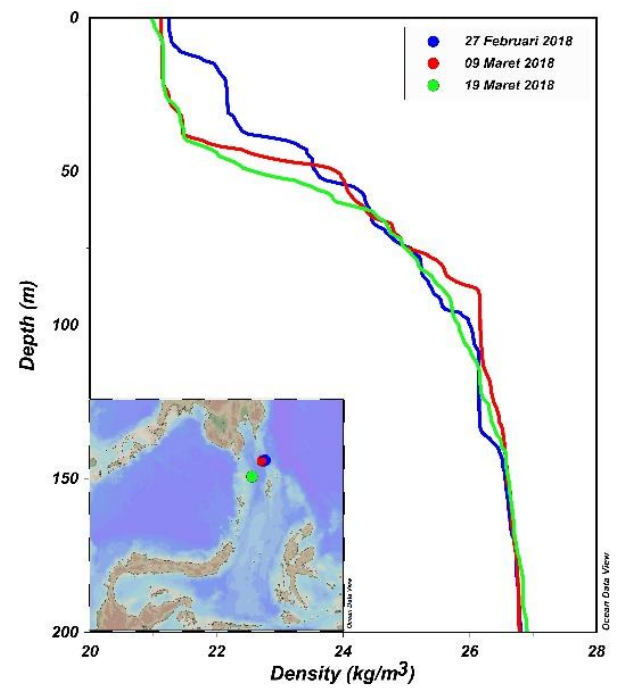

a)

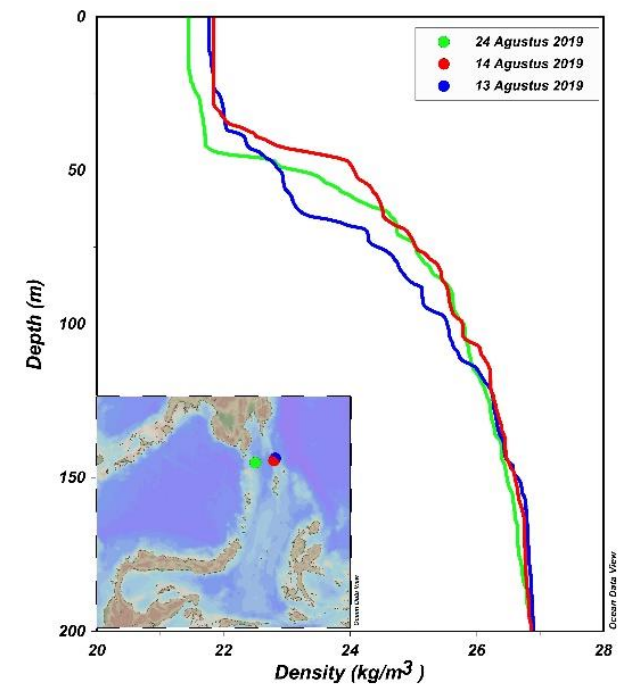

b)

Gambar 7. Profil vertikal densitas bulanan di Laut Filipina a). argo float musim barat b). argo float musim timur

penangkapan ikan sebesar 28.000 ton atau $4 \%$ dari total penangkapan ikan di Filipina. Menurut Kepmen-KP 50 (2017), Laut Maluku memiliki potensi perikanan sebesar $>300.000$ ton per tahun. Data perikanan tangkap di Laut Maluku bagian utara dan Laut Filipina masih berupa potensi dan hubungan daerah tangkapan antar kedua perairan ini belum diteliti. Kedua perairan yang dihubungkan oleh MC yang membuat interaksi antara organisme di perairan tersebut menjadi menarik.

\section{KESIMPULAN}

Laut Maluku bagian utara dan Laut Filipina memiliki kesamaan kecepatan angin di musim timur $(5,3 \mathrm{~m} / \mathrm{s})$. Kesamaan kecepatan angin tidak diikuti dengan konsentrasi chl-a di kedua perairan. Konsentrasi chl-a di Laut Maluku bagian utara lebih tinggi 4 kali lebih besar dibandingkan dengan Laut Filipina saat musim timur. Kenaikan chl-a di Laut Maluku bagian utara dipengaruhi oleh kecepatan angin yang menyebabkan coastal upwelling. Mekanisme coastal upwelling sangat berpengaruh terhadap chl-a di Laut Maluku bagian utara. Sabaliknya, Laut Filipina memiliki nilai chl-a rendah di sepanjang tahun, walaupun memiliki kecepatan angin tinggi disetiap musimnya. Hal tersebut membuktikan interaksi atmosfer dan laut di Laut Maluku bagian utara lebih dominan dibandingkan dengan Laut Filipina.

\section{DAFTAR PUSTAKA}

Acker, J.G., Vasilkov, A., Nadeau, D. \& Kuring, N. 2004. Use of Seawifs Ocean Color Data to Estimate Neritic Sediment Mass Transport from Carbonate Platforms for Two Hurricane-Forced Events. Coral Reefs. 23: 39-47.

Ando, K. \& McPhaden, M.J. 1997. Variability of Surface Layer Hydrography in the Tropical Pacific Ocean. Journal of Geophysical Research. 102(C10):23,063-23,078.

FAO. 2000. Information on Fisheries Management in The Republic Of The Philippines. Diakses pada 5 April 2020, dari http://www.fao.org/fi/oldsite/fcp/en/phl/body .html.

Gordon, A.L. 2005. Oceanography of Indonesian Seas and Their Throughflow. Oceanography. 18(4):14-27.

Hsieh, W. W. and G. J. Boer. 1992. Global climate change and ocean upwelling. Fisheries Oceanogr. 1(4): 333-338.

Jian, Y.Y., Tao, X., Liang, S. \& Fei, F.Y. 2012. Summer Monsoon Impacts on Chlorophyll-a Concentration in the Middle of the South China Sea: Climatological Mean and Annual Variability. Atmospheric and Oceanic Science Letters. 5(1):15-19.

Keputusan Menteri Kelautan dan Perikanan Republik Indonesia Nomor 50 Tahun 2017 Estimasi Potensi, Jumlah Tangkapan yang di 
Perbolehkan, dan Tingkat Pemanfaatan Sumber Daya Ikan di Wilayah Pengelolaan Perikanan Negara Republik Indonesia. 22 Desember. Menteri Kelautan Dan Perikanan Republik Indonesia. Jakarta.

Nugroho, D., Larrouy, A.K., Gaspar, P., Lyard, F., Reffray, G. \& Tranchant, B. 2018. Modelling Explicit Tides in The Indonesian Seas: An Important Process For Surface Sea Water Properties. Marine Pollution Bulletin. 131:7-18.

Nurdin S., M. A. Mustapha, T. Lihan, M. Zainuddin. 2017. Applicability of remote sensing oceanographic data in the detection of potential fishing grounds of Rastrelliger kanagurta in the archipelagic waters of Spermonde, Indonesia. Fisheries Research. 196: $1-12$.

Ren, Q., Li, Y., Wang, F., Song, L., Liu, C. \& Zhai, F. 2018. Seasonality of the Mindanao Current/Undercurrent System. Journal of Geophysical Research: Oceans. 123:11051122.

Sachoemar, S.I, Yanagi, T. \& Aliah, R.S. 2012. Variability of Sea Surface Chlorophyll-a, Temperature and Fish Catch within Indonesian Region Revealed by Satellite Data. Marine Research in Indonesia, 37(2):75-87.

Schönau, M.C., Rudnick, D.L., Cerovecki, I., Gopalakrishnan, G., Cornuelle, B.D., McClean, J.L. \& Qiu, B. 2015. The Mindanao Current: Mean structure and connectivity. Oceanography, 28(4):34-45.

Shi, W. \& Wang, M. 2007. Observations of a Hurricane Katrina-induced phytoplankton bloom in the Gulf of Mexico. Geophysical Research Letters. 34:1-5.

Susanto, R.D., Gordon, A.L. \& Sprintall, J. 2007. Observations and Proxies of the Surface
Layer Throughflow in Lombok Strait. Journal of Geophysical Research. 112:164174.

Susanto, R.D. \& Song, Y.T. 2014. Indonesian Throughflow Proxy from Satellite Altimeters and Gravimeters. Journal of Geophysical Research: Oceans. 120:371-382.

Trujillo, A.P. \& Thurman, H.V. 2011. Essensials of Oceanography (10th Edition). 2005 Pearson Education, Inc. Amerika Serikat. $577 \mathrm{p}$.

WAMDI group. 1988. "The WAM model: A third generation ocean wave prediction model. Journal of Physical Oceanography,18:17751810.

Wang, J.J. \& Tang, D.L. 2014. Phytoplankton Patchiness During Spring Intermonsoon in Western Coast of South China Sea. Deep-Sea Research II. 101:120-128.

Wirasatriya, A., Setiawan, R.Y. \& Subardjo, P. 2017. The Effect of ENSO on the Variability of Chlorophyll-a and Sea Surface Temperature in the Maluku Sea. IEEE Journal of Selected Topics in Applied Earth Observations and Remote Sensing. 10(12): 5513-5518.

Wirasatriya, A., Sugianto, D.N., Helmi, M., Setiawan, R.Y., \& Koch, M. 2019. Distinct Characteristics of SST Variabilities in the Sulawesi Sea and the Northern Part of the Maluku Sea During the Southeast Monsoon. IEEE Journal of Selected Topics in Applied Earth Observations and Remote Sensing. 12(6):1763-1770.

Zainuddin, M., Farhum, A., Safruddin, S., Selamat, M.B., Sudirman, S., Nurdin, N., Syamsuddin, M., Ridwan, M. \& Saitoh, S.I. 2017. Detection of Pelagic Habitat Hotspots for Skipjack Tuna in the Gulf of Bone-Flores Sea, Southwestern Coral Triangle Tuna, Indonesia. PloS One. 12(10):1-19. 